\title{
Cause-Related Marketing as A Commercially and Socially Oriented Activity: What Factors Influence and Moderate the Purchasing Intentions?
}

\author{
Karina Adomaviciute1, Goga Bzikadzeㄹ, Joseph Cherian², Sigitas Urbonavicius ${ }^{1}$ \\ ${ }^{1}$ Vilnius University \\ Sauletekio al. 9, LT-10222, Vilnius Lithuania \\ E-mail.karina.adomaviciute@gmail.com,goga.bzikadze@yahoo.com, sigitas.urbonavicius@ef.vu.lt \\ ${ }^{2}$ Graham School of Management \\ Saint Xavier University \\ 3700 W. 103rd Street, IL 60655, Chicago, US \\ E-mail.cherian@sxu.edu
}

cross $^{\text {ref }}$ http://dx.doi.org/10.5755/j01.ee.27.5.15166

\begin{abstract}
Cause-related marketing uniquely integrates business objectives with social causes, thus simultaneously satisfying usual consumer needs and moral considerations to support social campaigns. As cause-related marketing (CRM) becomes more prevalent, companies will need to be more effective and efficient in launching cause-related marketing campaigns. Simply having a cause-related marketing campaign was once sufficient to distinguish a company; increasing competitiveness in this arena means that campaigns have to be more distinctive and pertinent to successfully gain a position against competitors. While numerous studies have identified factors that influence consumer intention to purchase cause-related products, just a few of them have examined moderating influences. Therefore, this study sought to identify factors that moderated the influence of personal characteristics on the intention to purchase cause-related products. Data were obtained via online surveys from 393 English speaking Lithuanian students. Linear regression and moderating impact analysis were used in order to test seven hypotheses. Results confirmed that altruism, materialism and individualism have positive direct relationships with the intention to purchase cause-related products; product type and guilt did not have a moderating effect on those relationships, but cause involvement is an important moderator. These findings contribute to the theory of causerelated marketing by identifying moderators as being a specific type of personal characteristic (e.g., cause-involvement) and ruling out others (e.g., guilt), or product type. Furthermore, these findings provide insights to marketing managers for planning and positioning cause-related marketing campaigns by showing what factors amplify the effects of altruism, materialism and individualism in this context.
\end{abstract}

Keywords: Cause-Related Product, Materialism, Individualism, Altruism, Cause Involvement, Guilt, Product Type.

\section{Introduction}

Partnering businesses with charitable activities is increasingly common, and numerous companies are trying to implement cause-related marketing (CRM) strategies to improve sales and maintain favourable brand image (Barone et al., 2007), enhance brand awareness, and differentiate their products (Cheron et al., 2012). Furthermore, it is an effective way for a company to add to its social responsibility activities, as CRM is a philanthropic activity when the companies donate money to a social cause with every purchase (Chang, 2008; Lii \& Lee, 2012).

As the use of CRM increases, companies need to have knowledge of potential determinants influencing consumer's intention to purchase cause-related products, in addition to product related factors influencing purchase intentions (Chang, 2008). Despite the large number of studies about variables influencing consumer's intention to purchase cause-related products, there are few about how the personal characteristics of a consumer influence the intention to purchase cause-related products. This research gap is reiterated by a number of authors (Hyllegard et al., 2010, Goldsmith \& Clark, 2012; Bennett, 2003; Gupta \&
Pirsch, 2006). Therefore, this paper concentrates on the research problem - how certain personal characteristics affect intention to purchase cause-related products, and what factors exert a moderating influence on this relationship. The study aims to disclose influence of the personal characteristics (altruism, materialism, individualism) on the intention to purchase cause-related products, and especially - to analyze the variables that might have moderating impact on the above mentioned factors.

\section{Consumer Characteristics That Influence Intention to Purchase Cause-Related Product}

Numerous authors agree that consumer-related characteristics have the major influence on general consumer attitudes, which in turn determines their involvement in cause-related marketing campaigns (Ross et al., 1992; Bennett, 2003; Proenca \& Pereira, 2008). Consumer demographics (Hyllegard et al., 2010; Bennett, 2003; Cheron et al., 2012), lifestyle (Bigne-Alcaniz et al., 2010), value-related characteristics (altruistic, hedonic, utilitarian), materialism (Goldsmith \& Clark, 2012; Bennett, 
2003), individualism (Cornwell \& Coote, 2003; Bennett, 2003), trust (Till \& Nowak, 2000) have been found to have an influence on the consumer's intention to purchase causerelated products; however, the studies show rather diverse results (Proenca \& Pereira, 2008; Strahilevitz \& Myers, 1998).

Consumer demographics (mainly - age and gender) are found to have large influence on general consumer attitudes, and on their willingness to be involved in the cause-related marketing campaign (Ross et al., 1992; Cheron et al., 2012; Hyllegard et al., 2010, Barnes, 1992, Moosmayer \& Fulijahn 2010; Proença \& Pereira, 2008).

Along with the other factors, value related characteristics (such as hedonism, utilitarianism and altruism) can influence consumer attitudes and purchasing behaviour in general (Strahilevitz \& Myers, 1998; Proença \& Pereira, 2008; Okada, 2005; Chang \& Chen, 2009). Those characteristics might define the specific motivation of consumers to support social causes and will affect participation in cause-related marketing campaign, as the main purchase incentive (Strahilevitz \& Myers, 1998). More specifically, consumption of hedonic products activates feeling of guilt, which pushes consumers to take part in cause-related marketing campaigns (Subrahmanyan, 2004). Therefore, even though hedonic consumption is generally linked with the personal desire for pleasure, hedonic consumers more likely have positive intention to purchase cause-related products (Arnold \& Reynolds, 2003). Likewise, Proença \& Pereira (2008) emphasize that hedonic shopping motivations influence consumer attitudes to support CRM campaigns, and their desire for social responsibility is enhanced.

Conversely, utilitarian shopping does not directly affect purchase intent in CRM situations. Utilitarian motivation is oriented towards more practical satisfying of needs, and it does not necessarily influence consumer's intention to purchase cause-related products (Strahilevitz \& Myers, 1998). Therefore, in comparison to utilitarian consumption, hedonic consumption enhances altruistic feelings and the intention to purchase cause-related products is expressed more strongly (Strahilevitz \& Myers, 1998; Okada, 2005).

Altruism is considered to be a core variable which moves consumers to support social causes, increasing their intention to be more socially responsible members of society. Webb \& Mohr (1998) emphasize that consumers get double benefit while purchasing cause-related products, as the product fulfils the functional needs for which they bought the product, and the CRM campaign fulfils their altruistic needs by helping a social cause. Strahilevitz \& Myers (1998) describe altruism as the consumption of a "warm glow" and the process of buying internal satisfaction. Whenever consumers are sure that a company has altruistic desires while sponsoring a social cause, their desire to support the social cause is much stronger and positive attitudes arise in their mind regarding the sponsoring organization (Gupta \& Pirsch, 2006). Proença and Pereira (2008) state that altruism is a pure source of motivation for the consumers to be part of cause-related marketing campaigns, as it makes them to feel psychologically satisfied. According to Gupta \& Pirsch (2006), when the altruistic feelings are enhanced in consumer's mind, they make an individual more socially responsible, and they trust the cause supporter (a company) more.

Trust has been considered as one of the most influential factors in CRM and can have significant impact on the individual's intention to support the campaign (Webb \& Mohr, 1998). However, if the image of the sponsoring company is negative, consumers might not trust company's pro-social behaviour to support the cause (Till \& Nowak, 2000). According to Grau \& Folse (2007), when consumers are involved in the cause, they have better understanding of the issues and it positively affects their trust level towards the CRM campaign.

Numerous studies show that materialism is an important personal characteristic that influences the consumer's consumption behaviour (Goldsmith \& Clark, 2012). Goldsmith \& Clark (2012) describe materialism as a value orientation to achieve material possessions and consequent social acknowledgment. Likewise, Wymer \& Samu (2009) state that materialists consider their possessions and acquisitions as being the most important assets in their life, which makes them feel happy and satisfied. In addition, Bennett (2003) states that materialists strive all the time to accumulate products that have external symbolic value, so they can enhance their social status. Therefore, the emphasis on hedonic or utilitarian aspects in a CRM campaign (for example, using products that are more of hedonic or of utilitarian nature) might have the influence on a materialistic consumer's intention to participate in the cause-related marketing campaign (Strahilevitz \& Meyers, 1998). Individuals with a high level of materialism have been found to have positive attitudes towards the companies supporting worthy social causes (Bennett, 2003). In addition, materialists are considered to be more influenced and attracted by the cause-related marketing campaign when the brand is well-known, i.e. when they can relate their selfconcept with the brand image (Wymer \& Samu, 2009). Therefore materialists are expected to have higher level of the positive response towards the cause-related marketing campaign as they are looking for yet another way to impress other society members (Bennett, 2003). Furthermore, Wymer \& Samu (2009) found that the individuals with higher levels of the materialism respond to the cause-related marketing campaign more positively than do individuals with the lower levels of materialism. According to Strahilevitz \& Myers (1998), some materialistic people have stronger feelings of guilt, which can affect their response to the CRM campaign.

Individualism is understood as the core characteristic influencing person's general attitudes towards the society and state that it shapes the self-concept of an individual (Bennet, 2003). Individualists move forward according to their own principles and they do not accept status quo, thus people with the high level of individualism would have positive attitudes towards the charities supporting personal freedom of others. Bennet (2003) also points out that the consumers with the high level of the individualism admire cause-related campaigns that empower others to develop different personal values and "make people to think". Whenever the main objective of a CRM campaign is clear, and whenever it has a strong relationship with their personal values, there will be higher response rate to the cause- 
related marketing campaign (Bennett, 2003). In addition, Kim \& Johnson (2013) state that people with high level of individualism try to define themselves as unique members of society with different mental attributes: values, traits, motives, abilities and the motivation to be independent. If these mental attributes match the aims of the CRM campaign and/or values of the participating company, individualists are likely to support the cause-related marketing campaigns launched by this organization (Cornwell \& Coote, 2003). Hence, Kim \& Johnson (2013) clearly emphasize that the individualists have stronger desire to support the CRM campaign when they are involved in the social cause as it accentuates their feelings of individuation.

However, while extant literature on consumer related characteristics shows the importance of those characteristics on consumer attitudes towards the cause-related marketing campaigns, the influence of the altruism, materialism and individualism on consumer's intention to purchase causerelated products remains not fully explored (Goldsmith \& Clark, 2012; Bennett, 2003; Gupta \& Pirsch, 2006).

\section{Guilt, Cause Involvement and Product Type}

Moral emotions influence consumer behaviour (Coulter \& Pinto, 1995; Cotte et al., 2005). In some cases, feeling of the guilt (one of these moral emotions) is understood as a cognitive variable that affects altruistic desire and enhances willingness support cause-related marketing campaigns (Proença \& Pereira, 2008). There are various ways how the feeling of guilt motivates people to be part of CRM campaign. For example, Proença \& Pereira (2008) consider moral guilt as the result of not donating to charity and that creates negative associations in consumer's mind. Because non-participation makes them feel that they are avoiding social responsibility, this feeling of anticipated guilt makes them respond to the CRM campaigns positively. Consumption of hedonic products is also often followed by the feeling of guilt, which motivates consumers to buy cause-related products, in order to assuage the moral guilt (Strahilevitz \& Myers, 1998). Webb and Mohr (1998) emphasize that consumers actively try to avoid negative feelings/emotions (like guilt) after purchasing luxury products. According to Proença \& Pereira (2008) consumers buy cause-related products more readily when they want to overcome the feeling of guilt. Consequently, marketers may develop their marketing message in a way that enhances consumer feelings of guilt, and that increases sales (Burnett \& Lunsford, 1994). Kim \& Johnson (2013) state that individuals with the high level of guilt, have higher intention to buy cause-related products, as they want to get rid of guilt; in fact, guilt can be the key moral emotion influencing consumer desire to be part of a cause-related marketing campaign. In this sense, the influence of guilt is similar to the influence of materialism, and this suggests that guilt and materialism are highly correlated (Wymer \& Samu, 2009).

Cause involvement also has been considered as the important factor in CRM by influencing consumer attitudes and purchasing decisions (Bigne-Alcaniz et al., 2010; Grau \& Folse, 2007; Hajjat, 2003; Trimble \& Rifon, 2006). Historically, personal involvement in the cause was described as the degree to which personal interest was awakened by the stimulus of a specific issue (Antil, 1984), which is often based on personal interests and values (Zaichkowsky, 1985). Whenever consumers are deeply involved in a social cause, they have better understanding of the issues and they process CRM messages more carefully, which can enhance brand identity and image (Bigne-Alcaniz et al., 2010). According to Grau \& Folse (2007), consumers, who are more involved with a social cause, are more likely to participate in the cause-related marketing campaign. In addition, highly cause involved individuals identify sponsor brand much easier and their brand commitment is much higher (Grau \& Folse, 2007). Highly involved individuals expect to make large donations to the social cause as it is important to them (Hajjat, 2003). According to Grau \& Folse (2007) consumers more often donate to the social causes connected to their personal lives and they consider that connection as an important reason to donate. However, consumers, who have low involvement in the social cause, might support the CRM campaign if the partnering brand is familiar to them, as they may want to enhance their identification with the cause supporter brand (BigneAlcaniz et al., 2010). Companies understand the importance of consumer involvement with the cause and they link their CRM messaging with relevant partners in order to better engage their target audience with the cause, and, through that, with their brand.

The type of the product can also influence consumer involvement in the cause-related marketing campaign (Polonsky \& Macdonalds, 1999; Chang, 2011; Chang \& Liu, 2012). Chang \& Chen (2009) state that a CRM campaign has more positive response from consumers when the cause is linked with the luxury products, rather than with the practical (necessity) products. A similar difference is observed when products are categorised into hedonic and utilitarian ones. Donation incentives are more efficient with hedonic, frivolous, pleasure-oriented (luxury cars, cruises and etc.) products than the practical and functional products (refrigerators, vacuum cleaners, etc.) (Polonsky \& Macdonalds, 1999). Strahilevitz \& Myers (1998) quantified their observations regarding product types by noting that around $51 \%$ of the people participated in the survey stated that they would prefer the brand supporting social causes, while buying a "luxury" product. In contrast, only $36 \%$ of the respondents indicated a preference for the brand promoting a charity while buying "practical" products. This is reinforced by the observation that people are more likely support a social cause when they are spending large sums of money (Polonsky \& Macdonalds, 1999). Similar differences are seen in CRM participation when products are grouped into conspicuous (ownership and consumption easily noticed by public) and inconspicuous (ownership and consumption not visible) (Wymer \& Samu, 2009). Choices of the conspicuous goods are more significantly influenced by public or visible forces, while the choices of the inconspicuous products influenced much less (Steenkamp et al., 2003). This makes conspicuous products more suitable for cause-related marketing campaigns as they enhance social status and allow the buyers to be seen as socially responsible members of society (Wymer \& Samu, 2009). In addition to that, Strahilevitz \& Myers (1998) showed that there is the bigger chance of consumers purchasing causerelated products when the product is purchased as a gift. In 
this case both the buyer of the charity-linked product and the recipient of the gift feel accomplished by supporting the social cause. According to Wymer \& Samu (2009) causerelated product type and the price are two important variables which can have a significant influence in CRM. Chang \& Liu (2012) determined that consumers are more likely to choose a hedonic product offering a donation with a complementary cause (fit). This differs from the preference in case of a utilitarian product.

Summarising, the literature review suggest that guilt, cause involvement and product type may have impact on consumer behaviour in CRM. However, the way they interact with other factors are not entirely clear, and that is discussed next.

\section{Research Methodology}

Though studies on various aspects of altruism are abundant, it has not been studied extensively in the context of CRM campaigns, especially in the context of different product types. However, product types were seen earlier to generate different levels of participation in CRM campaigns (Strahilevitz \& Myers, 1998). The product type (e.g., luxury and practical products) can moderate the link between the altruism and purchase intention of a CRM product, because the link is stronger for altruistic products. Therefore, these hypotheses follow:

Hypothesis 1: The higher the consumer altruism the higher the purchase intention towards cause-related products.

Hypothesis 2: Altruism has stronger influence on purchase intention toward cause-related products for luxury products than for practical products.

Similarly, the literature review showed the underresearched link between materialism and intention to purchase CRM products. As before, literature suggests a moderating effect of materialism based on product types as it outlined earlier (Strahilevitz \& Myers, 1998; Goldsmith \& Clark, 2012). Materialism "works" in the context of the CRM in conjunction with the guilt. Therefore, these hypotheses follow:

Hypothesis 3: The higher the consumer materialism the higher the purchase intention towards cause-related products.

Hypothesis 4: The positive influence of consumer materialism on the purchase intention towards causerelated products gets stronger with the increase of guilt.

Hypothesis 5: Materialism has stronger influence on purchase intention towards cause-related products for luxury products than for practical products.

Materialistic consumers are often considered to have higher sense of individualism, as they strive to accumulate things, which brings them personal satisfaction and they are less influenced by circumstances (Goldsmith \& Clark, 2012; therefore, they are willing to base their behaviours on personal principles and beliefs. Individualistic consumers are likely to participate in cause-related marketing if it can differentiate them from others; this should work independent of product type. Therefore, these hypotheses follow:

Hypothesis 6: The higher the consumer individualism the higher the purchase intention towards cause-related products.

Hypothesis 7: Individualism has a stronger positive influence on purchase intention towards cause-related products when consumers have higher cause involvement.

All these hypotheses are summarised in the research model below (Figure 1).

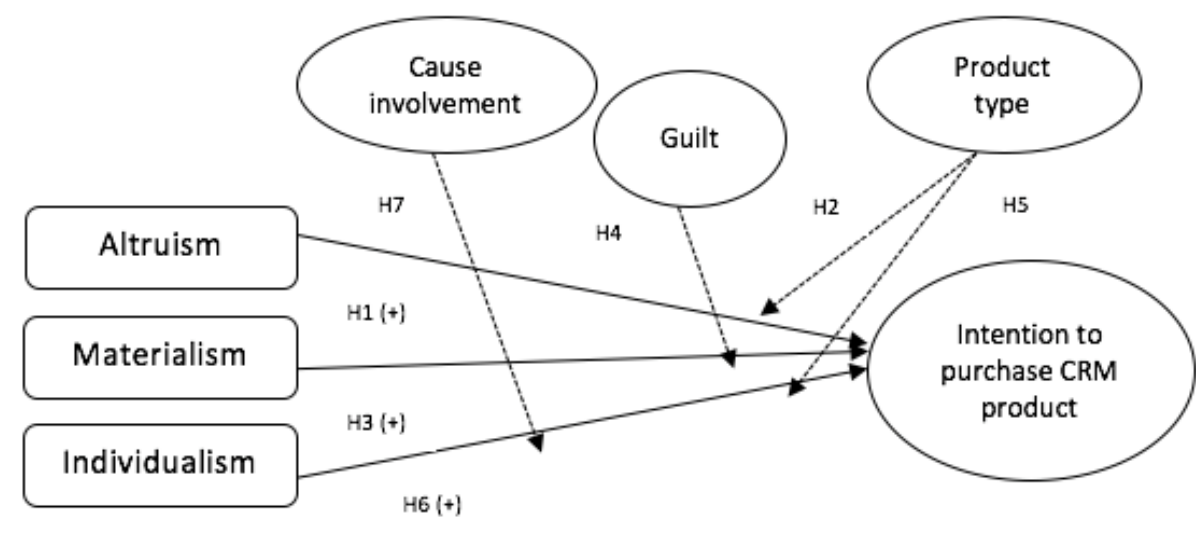

Figure 1. Research model

Data was collected using an online survey and a nonprobability (i.e., convenience) sampling. The questionnaire was sent to 742 Lithuanian students, 393 completed questionnaires were collected and used for further analysis. Non-response analysis showed no significant differences between respondents and non-respondents.

The research questionnaire consisted of 6 main constructs: altruism, materialism, individualism, guilt, cause involvement and purchase intention. Altruism was measured using 20-items Rushton et al. (1981) scale. 8items adapted Richins \& Dawson (1992) scale was chosen in order to measure materialism (Bakar et al., 2013). Individualism was measured using 8-items Singelis et al., (1995) scale. Guilt was measured using 5-items Bakar et al., (2013) adapted guilt measurement scale from Steenhaut \& Van Kenhove (2006). In order to measure cause 
involvement, 4-items scale by Maheswaran \& Meyers-Levy (1990) was chosen. Grau \& Folse (2007) adapted purchase intention scale to make it more relevant for the buying situation that involves cause-related marketing campaign. Therefore, 3-item adapted scale by Grau \& Folse (2007) was used in research to measure consumer's purchase intention. In all instances, 7-point Likert scale was employed.

In order to measure the product type, the statement "I am more likely to support a cause-related marketing campaign when I buy x" (Subrahmanyan, 2004), was modified in a way that " $x$ " indicated a choice between luxury and necessity products.

All Cronbach alphas were higher than 0.6 (Downing, 2004), therefore all the constructs have been used for further exploratory analysis (table 1).

\section{Analysis}

Linear regression was used to check the relationship and variance between the main variables; the impact of moderating variables was tested with PROCESS addition to SPSS (Hayes \& Preacher, 2014).

The linear regression was used to test H1, H3 and H6 hypothesis, in order to see the relationship between altruism, materialism, individualism and intention to purchase causerelated products.

According the results of linear regression, $F=70.609$ and $\mathrm{p}=0.00$ for ANOVA and $\mathrm{R}^{2}=0.353$, therefore model was statistically significant. Furthermore, all variables (altruism $\quad(b=0.395) \quad$ materialism $\quad(b=0.213) \quad$ and individualism $(b=0.115)$ ) had positive significant impact on the intention to purchase cause-related products. Results showed that the impact of altruism was the strongest. Therefore, H1, H3 and H6 hypothesis were supported.

In order to test $\mathrm{H} 2, \mathrm{H} 4, \mathrm{H} 5$ and $\mathrm{H} 7$ and to check the moderator impact of the product type, cause involvement and guilt on intention to purchase cause related products, the PROCESS regression plug in was used (Hayes \& Preacher, 2014).

First of all we tested the moderating impact of product type on the relationship between altruism and intention to purchase cause-related products. Moderation is shown up by a significant interaction effect, and, according to the PROCESS procedure, in this case the interaction was insignificant, $(b=-0.0489,95 \%$ CI [-0.3001, 0.2024], $t=-$ $0.3826, \mathrm{p}=0.7023)$. This means that the relationship between altruism and intention to purchase cause-related products is not moderated by the product type. Therefore, $\mathrm{H} 2$ is rejected.

Next, H4 was tested to check for moderating impact of guilt on the relationship between materialism and intention to purchase cause-related products. Results show that the interaction between guilt and materialism $(b=0.0257,95 \%$ CI [-0.0743, 0.1256], $\mathrm{t}=0.5054, \mathrm{p}=0.6136)$ is not statistically significant, indicating that the relationship between the materialism and intention to purchase cause-related products is not moderated by the guilt. H4 hypothesis was rejected.

In addition to the above discussed results, the moderator influence of the product type on the relationship between materialism and intention to purchase cause-related products was tested. Results show that the interaction between product type and materialism $(b=0.1496,95 \%$ CI $[-0.0834,0.3827], \mathrm{t}=1.2626, \mathrm{p}=0.2075)$ is not statistically significant, which means that the relationship between the materialism and intention to purchase cause-related products is not moderated by the product type. Therefore H5 hypothesis was rejected.

Finally, H7, checking the moderating influence of the cause involvement on the relationship between individualism and intention to purchase cause-related products was tested. Results show that the interaction between cause involvement and individualism $(b=-0.1476$, $95 \%$ CI [-0.2767 -0.0184], $\mathrm{t}=-2.2465, \mathrm{p}=0.0252)$ is significant, which confirmed that individualism had positive direct impact on the intention to purchase cause-related products, when the moderating influence of the cause involvement was considered. Therefore, $\mathrm{H} 7$ hypothesis was confirmed. To interpret the moderation effect, conditional effect analysis was performed. Results show that: 1) when cause involvement is low, there is a significant positive relationship between individualism and intention to purchase cause-related products, $\mathrm{b}=0.3553,95 \%$ CI $[0.1433,0.5672], \mathrm{t}=3.2953, \mathrm{p}=0.0011 ; 2)$ at the mean value of cause involvement, there is a significant positive relationship between individualism and intention to purchase cause-related products, $\mathrm{b}=0.1927,95 \% \mathrm{CI}$ [0.0111, 0.3743], $\mathrm{t}=2.0867, \mathrm{p}=0.0376 ; 3)$ when cause involvement is high, there is a non-significant positive relationship between individualism and intention to purchase cause-related products, $b=0.0302,95 \%$ CI [$0.2178,0.2782$ ], $\mathrm{t}=0.2394, \mathrm{p}=0.8109$.

To sum up the testing of hypotheses, the statistical tests allow confirming the hypotheses $\mathrm{H} 1, \mathrm{H} 3, \mathrm{H} 6$ and $\mathrm{H} 7$.

Table 1

Results of the Reliability Analysis

\begin{tabular}{|c|c|}
\hline Variable & Cronbach's alpha \\
\hline Altruism & 0.868 \\
\hline Materialism & 0.809 \\
\hline Individualism & 0.644 \\
\hline Product type & - \\
\hline Cause involvement & 0.645 \\
\hline Guilt & 0.740 \\
\hline
\end{tabular}

Note: $\mathrm{N}=393$. Dependent variable: intention to purchase cause related products.

Furthermore, altruism, individualism and materialism had direct positive connection with consumer's intention to purchase cause-related products. Likewise, when altruism, materialism and individualism were higher consumer's intention to purchase cause-related products was higher. The moderating influence of cause involvement on the relationship of the individualism and intention to purchase cause-related products was confirmed. On the other hand, $\mathrm{H} 2, \mathrm{H} 4$ and $\mathrm{H} 5$ hypotheses were rejected, as guilt and product type did not impact the relationship of the altruism/materialism and intention to purchase causerelated product

\section{Discussion and Conclusions}

The objective of this study was two-fold. First, the study tested the influence of three personal characteristics 
(altruism, materialism, individualism) on intentions to purchase cause-related products; of the three, only altruism has received wider attention in research. The moderating influence of these three personal variables on purchase intentions has not been studied (Strahilevitz \& Myers, 1998; Goldsmith \& Clark, 2012; Bennett, 2003; Proença \& Pereira; 2008). Second, literature suggested strong reasons to expect product type, guilt and cause involvement to have a moderating influence between the three characteristics and purchase intention.

The first objective and related hypotheses were confirmed; altruism, materialism and individualism have positive influence on intention to purchase cause-related products. The influence of the latter two is less strong than in case of the altruism, but statistically significant. Together the three factors explain more than one third of the total variance, and this is the first important conclusion of this study.

The analysis of moderation produced more conflicting result. Rather surprisingly, the product type did not generate its moderating influence on the two analysed relationships (altruism $\rightarrow$ intention; and materialism $\rightarrow$ intention). This requires further study as the literature review and hypotheses development showed strong reasons to expect these effects.

The moderating influence of guilt on the relation between the materialism and intention was also not significant. This is rather important observation regarding the type of the relationship between the three factors, since relation of guilt and materialism on intention to purchase CRM products are confirmed by former studies (guilt) and by both former and the current study (materialism). The results of this study suggest looking for other type of interaction between the variables.

The moderating influence of the cause involvement on the relationship of individualism $\rightarrow$ intention was confirmed, and this is a rather new insight on the studying consumer behaviour in the CRM context, and can be used in further studies as well as in developing managerial insights. This can be considered as the second summarised finding/conclusion of this study.

The contribution of this study towards CRM theory is the exploration and partial confirmation of a variety of moderation effects; in a field that primarily studied maineffects, this study shows a pathway that other disciplines used to evolve towards interaction-effects based studies. The contribution towards CRM management is that there are specific person-based and product-type variables to consider when designing campaigns. The pattern of influence within the CRM context is as complex as, if not more complex than, other consumption behaviours. Therefore, campaign designs must move beyond an expectation so simple.

This study has certain limitations. One of them is the type (students) and scope (one country based) of the sample, which does not allow broad generalizations. Another limitation occurs from the design of the survey. Though it is appropriate to get opinions of respondents without the precisely describing the social cause, this may to some extent impact results of the survey. It is likely that respondents prefer concrete descriptions, and in future studies spelling the specific characteristics of campaigns will be suggested.

\section{References}

Antil, J. H. (1984). Conceptualization and operationalization of involvement. Advances in Consumer Research, 11(1), 203209.

Arnold, M. J., \& Reynolds, K. E. (2003). Hedonic shopping motivations. Journal of retailing, 79(2), 77-95. https://doi.org/10.1016/S0022-4359(03)00007-1

Bakar, A., Lee, R., \& Hashim, N. H. (2013). Parsing religiosity, guilt and materialism on consumer ethics. Journal of Islamic Marketing, 4(3), 232-244. https://doi.org/10.1108/JIMA-04-2012-0018

Barnes, N. G. (1992). Determinants of consumer participation in cause-related marketing campaigns. American Business Review, 10(2), 21-24.

Barone, M. J., Norman, A. T., \& Miyazaki, A. D. (2007). Consumer response to retailer use of cause-related marketing: is more fit better? Journal of Retailing, 83(4), 437-445. https://doi.org/10.1016/j.jretai.2007.03.006

Bennett, R. (2003). Factors underlying the inclination to donate to particular types of charity. International Journal of Nonprofit and Voluntary Sector Marketing, 8(1), 12-29. https://doi.org/10.1002/nvsm.198

Bigne-Alcaniz, E., Curras-Perez, R., Ruiz-Mafe, C., \& Sanz-Blas S. (2010). Consumer behavioural intentions in causerelated marketing. The role of identification and social cause involvement. International Review on Public and Nonprofit Marketing, 7(2), 127-143. https://doi.org/10.1007/s12208-010-0053-6

Burnett M. S., \& Lunsford D. A. (1994). Conceptualizing Guilt in the Consumer Decision-making Process. Journal of Consumer Marketing, 11(3), 33-43. https://doi.org/10.1108/07363769410065454

Chang, C. T. (2008). To Donate or Not to Donate? Product Characteristics and Framing effects of Cause-Related Marketing on Consumer Purchase Behavior. Psychology and Marketing, 25(12), 1089-1110. https://doi.org/10.1002/mar.20255

Chang C. T., \& Chen T. T. (2009). Consumer Response to Harmful Products With Cause-Related Marketing: Influences of Product-Cause Fit and Product Type, in NA - Advances in Consumer Research Volume 36, eds. Ann L. McGill and Sharon Shavitt, Duluth, MN : Association for Consumer Research, 793-794. 
Chang, C. T. (2011). Guilt Appeals in Cause-Related Marketing. The Subversive Roles of Product Type and Donation Magnitude. International Journal of Advertising, 30(4), 587-616. https://doi.org/10.2501/IJA-30-4-587-616

Chang, C. T., \& Liu, H. W. (2012), Goodwill hunting? Influences of product-cause fit, product type, and donation level in cause-related marketing. Marketing Intelligence \& Planning, 30 (6), 634-652. https://doi.org/10.1108 /02634501211262609

Cheron E., Kohlbacher F., \& Kusuma K. (2012).The effects of brand-cause fit and campaign duration on consumer perception of cause-related marketing in Japan. Journal of Consumer Marketing, 29(5), 357-368. https://doi.org/10. 1108/07363761211247479

Cornwell, T. B., \& Coote, L. V. (2003). Corporate sponsorship of a cause: the role of identification in purchase intent. Journal of Business Research, 58(3), 268-276. https://doi.org/10.1016/S0148-2963(03)00135-8

Cotte, J., Coulter, R., \& Moore, M. (2005). Enhancing or disrupting guilt: the role of credibility and perceived manipulative intent. Journal of Business Research, 58(3), 361-368. https://doi.org/10.1016/S0148-2963(03)00102-4

Coulter, R. H., \& Pinto, M. B. (1995). Guilt appeals in advertising: what are their effects? Journal of Applied Psychology, 80(6), 697-705. https://doi.org/10.1037/0021-9010.80.6.697

Downing, S. M. (2004). Reliability: on the reproducibility of assessment data. Medical Education, 38(9), 1006-1012. https://doi.org/10.1111/j.1365-2929.2004.01932.x

Goldsmith, R. E., \& Clark, R. A. (2012). Materialism, Status Consumption, and Consumer Independence. Journal of Social Psychology, 152(1), 43-60. https://doi.org/10.1080/00224545.2011.555434

Grau, S. L., \& Folse, J. A. G. (2007). Cause-related marketing (CRM): The influence of donation proximity and messageframing cues on the less-involved consumer. Journal of Advertising, 36(4), 19-33. https://doi.org/10.2753/JOA00913367360402

Gupta Sh., \& Pirsch J. (2006).The company-cause-customer fit decision in cause-related marketing. Journal of Consumer Marketing, 23(6), 314-326. https://doi.org/10.1108/07363760610701850

Hayes, A. F., \& Preacher, K. J. (2014). Statistical mediation analysis with a multicategorical independent variable. British Journal of Mathematical and Statistical Psychology, 67(3), 451-470. https://doi.org/10.1111/bmsp.12028

Hajjat, M. M. (2003). Effect of Cause-Related Marketing on Attitudes and Purchase Intentions: The Moderating Role of Cause Involvement and Donation Size. Journal of Nonprofit \& Public Sector Marketing, 11(1), 93-109. https://doi.org/10.1300/J054v11n01_07

Hyllegard, K. H., Yan, R. N., Ogle J. P., \& Attmann J. (2010). The influence of gender, social cause, charitable support, and message appeal on Gen Y's responses to cause-related marketing. Journal of Marketing Management, 27(1/2), 100-123. https://doi.org/10.1080/02672571003683755

Kim, J. E., \& Johnson, K. K. (2013). The impact of moral emotions on cause-related marketing campaigns: A cross-cultural examination. Journal of business ethics, 112(1), 79-90. https://doi.org/10.1007/s10551-012-1233-6

Lii, Y. Sh., \& Lee, M. (2012). Doing Right Leads to Doing Well: When the Type of CSR and Reputation Interact to Affect Consumer Evaluations of the Firm. Journal of Business Ethics, 105(1), 69-81. https://doi.org/10.1007/s10551-0110948-0

Maheswaran, D., \& Meyers-Levy, J. (1990). The influence of message framing and issue involvement. Journal of Marketing research, 27(3), 361-367. https://doi.org/10.2307/3172593

Moosmayer D. C., \& Fuljahn A. (2010).Consumer perceptions of cause related marketing campaigns. Journal of Consumer Marketing, 27(6), 543-549. https://doi.org/10.1108/07363761011078280

Okada, E. M. (2005). Justification effects on consumer choice of hedonic and utilitarian goods. Journal of Marketing Research, 42(1), 43-53. https://doi.org/10.1509/jmkr.42.1.43.56889

Polonsky, M. J., \& Macdonald, E. K. (1999). Exploring the link between cause-related marketing and brand building. International Journal of Nonprofit and Voluntary Sector Marketing, 5(1), 46-57. https://doi.org/10.1002/nvsm.96

Proenca, J. F., \& Pereira, I. V. (2008). Exploring the consumption of charity-linked products. International Review on Public and Nonprofit Marketing, 5(1), 53-69. https://doi.org/10.1007/s12208-008-0007-4

Richins, M. L., \& Dawson, S. (1992). A consumer values orientation for materialism and its measurement: Scale development and validation. Journal of Consumer Research, 19(3), 303-316. https://doi.org/10.1086/209304

Ross, J. K., Patterson, L. T., \& Stutts, M. A. (1992). Consumer Perceptions of Organizations that Use Cause-Related Marketing. Journal of the Academy of Marketing Science, 20(1), 93-97. https://doi.org/10.1007/BF02723480

Rushton, J. P., Chrisjohn, R. D., \& Fekken, G. C. (1981). The altruistic personality and the self-report altruism scale. Personality and individual differences, 2(4), 293-302. https://doi.org/10.1016/0191-8869(81)90084-2 
Karina Adomaviciute, Goga Bzikadze, Joseph Cherian, Sigitas Urbonavicius. Cause-Related Marketing as ...

Singelis, T. M., Triandis, H. C., Bhawuk, D. P., \& Gelfand, M. J. (1995). Horizontal and vertical dimensions of individualism and collectivism: A theoretical and measurement refinement. Cross-cultural research, 29(3), 240-275. https://doi.org/10.1177/106939719502900302

Steenhaut, S., \& Van Kenhove, P. (2006). The mediating role of anticipated guilt in consumers' ethical decision-making. Journal of Business Ethics, 69(3), 269-288. https://doi.org/10.1007/s10551-006-9090-9

Steenkamp, J. B. E., Batra, R., \& Alden, D. L. (2003). How perceived brand globalness creates brand value. Journal of International Business Studies, 34(1), 53-65. https://doi.org/10.1057/palgrave.jibs.8400002

Strahilevitz, M. \& Myers, J. G. (1998). Donations to Charity as Purchase Incentives: How Well They Work: May Depend on What You Are Trying to Sell. Journal of Consumer Research, 24(4), 434-446. https://doi.org/10.1086/209519

Strahilevitz, M. A. (1999). The Effects of Product Type and Donation Magnitude on Willingness to Pay More for a CharityLinked Brand. Journal of Consumer Psychology, 8(3), 215-241. https://doi.org/10.1207/s15327663jcp0803_02

Subrahmanyan, S. (2004). Effects of price premium and product type on the cause-related brands: A Singapore perspective. Journal of Product \& Brand Management, 13(2), 116-124. https://doi.org/10.1108/10610420410529744

Till, B. D., \& Nowak, L. I. (2000). Toward effective use of cause-related marketing alliances. Journal of Product \& Brand Management, 9(7), 472-484. https://doi.org/10.1108/10610420010351394

Trimble, C. S., \& Rifon, N. J. (2006). Consumer perceptions of compatibility in cause-related marketing messages. International Journal of Nonprofit and Voluntary Sector Marketing, 11(1), 29-47. https://doi.org/10.1002/nvsm.42

Webb, D. J., \& Mohr, L. A. (1998). A typology of consumer responses to cause-related marketing: From skeptics to socially concerned. Journal of Public Policy \& Marketing, 17(2), 226-238.

Wymer, W., \& Samu, S. (2009). The influence of cause marketing associations on product and cause. International Journal of Nonprofit and Voluntary Sector Marketing, 14(1), 1-20. https://doi.org/10.1002/nvsm.348

Zaichkowsky, J. (1985). Measuring the Involvement Construct. Journal of Consumer Research, 12(3), 341-352. https://doi.org/10.1086/208520

The article has been reviewed.

Received in June, 2016; accepted in November, 2016 